\title{
PHOTOGRAPHY AS A MEANS OF DEPICTING GENIUS LOCI?
}

\author{
Iulia DOROFTEI \\ Babeş-Bolyai University, Cluj-Napoca, Faculty of Geography, ROMANIA \\ iulia.doroftei@yahoo.com \\ DOI: http://dx.medra.org/10.23740/TID120164
}

\section{ABSTRACT}

The paper aims to explore the concept of genius loci (spirit of a place) starting from Christian Norberg-Schulz's notable work "Genius Loci: Towards a Phenomenology of Architecture" and to reflect on the possibility of capturing the spirit of a place through photography. The problem arises in the context of a predominantly visual culture, where photography has become an accesible and omnipresent means of experiencing the world and, therefore, considered a convenient tool for gaining (a type of) knowledge. A photographic method of exploring the spirirt of the place could serve in understanding local characteristics, in identifying the elements that make a place unique and recognizible. Norberg-Schulz's position and other views on the concept of genius loci have been analysed. A photo-essay was employed in order to explore the spirit of the old town of Chefchaouen in Morocco and the ambiguity and dual nature of the concept. A critical reflection was conducted with respect to the results.

\section{INTRODUCTION}

It seems that, with the passing of time, the built environment has a great capacity of testimony and constancy. Somehow, while recording layers of history and social changes, it has continuity and ability to transcend time. Take the site of the Acropolis. Nowadays, it surely does not guard the same atmosphere as it did back in ancient times, but somehow the existent elements remind us of the spirit of the past and lead us back to that time. Can we precisely have a sense of antique Athens, can we become citizens inhabiting Ancient Greece while on site? Surely not. But we can feel that where we are, our sense of the place builds on those ancient elements still testified. They give us anchorage and testimony.

This is not to say that the built form has greater value than the intangible elements (e.g. rituals, traditions). As a matter of fact, nowadays, both are seen as components of the spirit of a place (Québec Declaration, 2008; Kapila, 2015). But, as Norberg-Schulz suggests, there is a certain stability that can be perpetuated through the built environment if some conditions are observed (like understanding the character and structure of the place). It seems that the built environment can be a concentration of time and meaning in material form. As professor loan (2008) states:

"Architecture materializes, it densifies the data of the existential space, it is what amplifies (it should and it can) the potential attributes of the 'always already' (Heidegger) which is the land of its placement. In this way it makes the genius of the place visible".

It is one of the reasons that led to this article focusing on the built environment, on the material aspects of genius loci. Perhaps, in a quest to understand if it facilitates a general consensus on 
the understanding of a place, regardless of the individual interpretations. Christian NorbergSchulz's work posed a particular interest because of its intent to mediate between structuralism and phenomenology. It seemed to give an objective understanding of place and genius loci while taking into account individual meanings and interpretation.

The initial question was if and how we can capture the concentration of meaning and manifestations of the spirit of a place and transmit it or make it available to the world. This was of interest because it would allow understanding of place specificity, of local characteristics that can be employed in the development of a territory and that can contribute to a strong character of a place. Given the proliferation of the visual in our day-to-day life, a further question was how and in what measure the genius loci can be understood through photographic methods or what kind of knowledge can they convey?

\section{METHODOLOGY}

The study comprised three stages: (1) the concept of genius loci, (2) approaches to photography, and (3) the exploration of the spirit of a place through a photographic essay together with a reflection on the results.

In a first instance, the focus was on understanding the concepts of place and genius loci as proposed by Norberg-Schulz: how they are defined, what their components are, how can a strong genius loci be created for a man-made place. Norberg-Schulz's work was a point of departure because his structured approach to the built environment and the concept of place deceive into believing in an essence of place that can be universally aknowledged and it is tempting enough to want to 'catch it'.

Other ways of approaching the concept were investigated in an attempt to grasp changes in understanding throughout time. I realised along the way the complexity and ambiguity of the concept and the gaps and oppositions between general consensus and individual experience, material and intangible, theory and physical manifestation.

An exploration of views on photography has been made to portray the changes in thought: from the representational to the sensory, perceptual, and performative.

The photographic essay was employed in an attempt to reveal information about the spirit of the old town of Chefchaouen in Maroc. The essay is based on photographs taken on the occasion of a visit there in September 2015. At that time, I empirically tried to 'sum up' the strong personality of the city. Having no previous knowledge or reflection on the concept of genius loci, but with a background in urbanism, I took the 'shotgun' approach in an attempt to put in visual terms what stroke me as particular to that place. Two weeks after my return, I revised the results and made a selection of relevant photographs which I placed in a separate folder.

I reviewed my selection with the occasion of this study reflecting on why I had decided to take certain photographs and why I considered relevant those that I placed in the final folder. I realised that in my attempt to understand and grasp the place, and also due to my academic formation as an urbanist, I had focused on the built environment as it has a strong character in itself and also because I wanted to catch the 'feeling' which I felt was generated by it. There was a clash, it seemed, between my intent at that time to portray the place 'exactly as I saw it', while concomitently revealing what I felt during my stay in that place, what impressions it made on me. Therefore, I realised the need to present these contradictions. 
I used Norberg-Schulz's thoughts to structure the visual analysis of the spirit of the place (from macro level to detail, looking at structure, earth-sky relationship, etc.) because of his systematic approach that seems to offer global, objective knowledge. I wanted to contradict it by adding another type of information that would convey the subjective experience of the place and the fact that this was at the base of the production of the visual material. In this case I opted for text.

\section{GENIUS LOCI DIALECTICS}

In order to answer the question if and how the spirit of a place can be understood through photographic methods, we must clarify the understanding of the term we are referring to. The purpose is not to ehaustively present the ideas revolving around the notion of genius loci, neither to classify the theories in scientific literature, but merely to bring into attention that the meaning of the term has been reinterpreted and adjusted over time.

Genius loci is a concept known to date back to Ancient Rome, when it was considered that places, as well as individuals, are inhabited by spirits (genii) (Turgeon, 2008, p. 2), each spirit being definitory for the thing or person that it accompanies (Norberg-Schulz, 1976, p. 18). Over time, the understanding and usage of the term has changed, from it being associated to rural and garden landscapes, in the eighteenth century, to predominant usage in architecture and urban planning fields (Jivén \& Larkham, 2003, p. 68). The concept became especially important when modernism brought with it the idea of progress understood as a new beginning, rejection of tradition and thus, universally aplicable principles with a disregard for local circumstances. In the preface of the work of Camillo Sitte (1992, p. VIII), Eftenie dates these tendencies even earlier, tracing them back to "pre-urbanists" stating about their view:

"There is a tendency [...] towards a standard order which, no matter the time and place, can be applied to any human group. The past is tabula rasa [...]".

We can understand hence, the raising concern for genius loci, for places with character and meaning, in a time when planning and building were made "no matter the time and place".

\section{On Christian Norberg-Schulz}

Norberg-Schulz's appeal was towards returning to place as "a concrete 'here' having its particular identity", a "qualitative, total phenomenon" that draws from "cultural traditions" and "environmental conditions" (Norberg-Schulz, 1976, p. 10). In his view, places cannot be objectively created out of abstract knowledge and solely based on functional criteria. They are made of concrete things which, put together, instill a certain character that overcomes the elements themselves, becoming "qualitative totalities of a complex nature". Places are associated with location, hence dependent on a certain geography, but their meaning should not be reduced to it (Norberg-Schulz, 1976, p. 10).

The concept of place is needed to understand genius loci as it is, in the view of Norberg-Schulz, the "spirit" or identity of a place and it is built by its meanings: "In general we may say that the meanings which are gathered by a place constitute its genius loci" (Norberg-Schulz, 1976, p. 170). In the case of man-made places, the genius loci manifests itself strongly when the place has unity, when it is perceived as a whole and when the elements relate in a similar way to the 
environment. They should relate in terms of two components by which a place is understood: space and character. Space denotes the organisation of elements, while character refers to "the general 'atmosphere'” (Norberg-Schulz, 1976, p. 11).

It is important to differentiate between character and genius loci. As mentioned above, character refers to the atmopshere of a place and to its determinants, to how the elements that define the space are. It is a time dependent atribute and is partly influenced by light - as a variable according to seasons and moments of day (Norberg-Schulz, 1976, p. 14). Character can be described using adjectives. However, genius loci is an expression of the place's structure as well as character, a resultant of these two. In the case of man-made places, they acquire genius loci through meaningful interpretation of the surrounding environment. To seize it, to capture it visually, means to be aware of all these aspects.

Also, Norberg-Schulz considers that "the individual genius loci is [...] part of a hierarchical system" (Norberg-Schulz, 1976, p. 42). He identifies "environmental levels" (countries, regions, landscapes, settlements and buildings) and a strong genius loci comes from referencing each level to the superior environmental level - e.g., settlements gather meaning from landscape, while the building is the condensed meaning of the settlement.

For Norberg-Schulz, the relationship earth-sky is fundamental in understanding places. In natural places, factors such as relief, water, vegetation interract, giving a particular expression to the relationship sky-earth and creating romantic, cosmic or classical landscapes (in reality, none of them are found in pure form).

Man-made places are related to the environment through the visualization, complementing, symbolization and gathering of meanings from it. A rural settlement is closely related to the environment and its genius loci is similar to that of the natural place, while, for urban settlements, the genius loci gains "roots" from the spirit of the locality but also comprises "cotents of general interest, contents which have their roots elsewhere, and which have been moved by means of symbolization" (Norberg-Schulz, 1976, pp. 56-58). (For details, see chapters II. Natural Places and III. Man-Made Places of the quoted work).

By proposing a structure of places (both man-made and natural) and a view on how man creates meaning, Norberg-Schulz attempts to trace guidelines to understanding and building meaningful environments. He does so by exploring "original" forces of places, that, if understood and interpreted, ensure the stability of the "genius loci". While this is arguable, his work is useful, because of the honourable intent of understanding how a strong image of place is created in time, how stability and change in thought and values could go hand in hand, how it is important to relate and interpret different environmental levels.

\section{Critiques on the work of Christian Norberg-Schulz}

However, Norberg-Schulz's idea of genius loci has been considered by some critics "as strongly traditional and nostalgic" (Wilken, 2013, p. 345), suited for ancien settlements and ways of building and not applicable to the contemporary fragmented and heterogenous urban environment. Others have criticised his understanding for being utopic and, more importantly, essentialist, with disregard to history, politics and ideology (Otero-Pailos, Edquist quoted by Wilken, 2013, pp. 346-347), because he assumes on the one hand a given, natural, cosmic reality that can be learned by any subject and the existence of "original meanings" of natural places (Haddad, 2010, p. 93) and on the other, a universal subject taken out of context and history. In his article, "The spirit of place in a multicultural society", professor O. Møystad (2012), analyzing 
Norberg-Schulz's thought, states that the place is seen by him as a geographical entity forger of identity for the individual and questions the shortcomings of this vision, especially in today's mobile society. As other critics, he points out that the idea of one's (single) identity attached and influenced by one place creates exclusion and leaves little room for the coexistence of people with different cultural backgrounds in the same geographical place. Moreover, it can serve as material for authoritarian regimes to mobilise population for political purposes (Edquist quoted by Wilken, 2013) based on an essentialist understanding of national identity and identity in general.

The idea of an essentialist notion of identity and place was also criticised by Massey (1994) in her work "Place, space and gender". She underlines that this kind of view implicitly means construction of boundaries, opposition of "one" to the "other" and exclusions. She defines place in terms of social relationships and argues that the shaping of the identity of a place is "also a product of interactions" (Massey, 1994, p. 120). Places have multiple identites and not a single, dominant image that perpetuates in time, but rather an image that is repeatedly contested and altered over time. Places can have "a character of their own", but "not a seamless coherent identity, a single sense of place which everyone shares" (Massey, 1994, p. 153).

\section{Other views on the concepts - place, genius loci, sense of place, character}

Place as a concept has been the focus of many authors in the last decades. In her essay "A critical review on the problematic nature of 'place' ", Veronica Ng associates this raising interest with the development of a feeling "of loss of meaning and identity of place" (Ng, 2012, p. 103), to "placelessness", associated, as stated earlier in this article, with the new modernist thinking. She identifies three types of theories on the defining of place: those referring to place as a social and cultural construct (authors like de Certeau, Giddens, Harvey, Featherstone, and Massey), those which highlight "the 'otherness' of place" (Ng, 2012, p. 110), like Foucault's view and the thinking of "place as a 'lived-experience'" - Relph, Tuan, Cassey, and Norberg-Schulz (Ng, 2012, p. 111).

A clear definition of place has not been pinpointed due to it always being situated either in a dialectic relationship between "space and place, global and local and universal and particular", either as a process submitted to reinvention, as a result of social relationship and/or cultural practices (Ng, 2012, p. 112). Other authors mention that place is an ambiguous concept because it has a simultaneously tangible and intangible nature. That is, it "commonly refers both to a space, setting or physical elements and to people's evaluations of it, reactions to it, and relationships with it" (Ng, 2012, p. 115). Authors reviewing the history of the concept of place (Casey, 1997, Curry, 2002 quoted by Ng, 2012) have noticed that its understanding is in a permanent state of change and emphasize "the need to contextualize the concept of place within its time" ( $\mathrm{Ng}, 2012, \mathrm{p} .117)$. What $\mathrm{Ng}$ herself identifies as an issue in place discourse is a lack of connection between the conceptual thinking and the physical manifestations of place.

Given the ambiguity of the notion of place, genius loci is also hard to be pinpointed. Most authors consulted agree on the fact that its definition poses difficulties as it is a deceitful term. Jivén \& Larkham (2001) make a great exploration of the use of the concept by different authors and state once more that there is not a clear agreement on the term. Also, some authors claim the perception of genius loci is facilitated by the "tourist view" others by long familiarity with the place, some argue over the individual vs. collective experience of a place, or for holistic vs. visually predominant experience (Jivén \& Larkham, 2001, p. 70). 
In the works focusing on the built environment, even when the term is not clearly defined, there appears to be a close association of genius loci with the identity of the settlement (NorbergSchulz, 1976), personality (Sharp, 1946 quoted by Jivén \& Larkham, 2001, p. 72)/ personalité (Conzen, 1949 quoted by Jivén \& Larkham, 2001, p. 72), "expressive intelligibility" (Walter, 1988 quoted by Jivén \& Larkham, 2001, p. 70), "intensity of wholeness" (Baron, 2008, p. 2) and it is worth noticing that most of the times the term appears when places have a strong image or it is wished that they gain it.

Jivén \& Larkham remark that, in the recent period, "people have tended to use the terms 'sense of place', 'character', 'appearance' and 'genius loci' indisciminately and interchangeably" and often character is understood only as "external appearance" (Jivén \& Larkham, 2001, pp.73-74) which is a narrow view of the concept. The authors themselves make a distinction when it comes to "character", but they use the terms "sense of place" and "genius loci" as synonyms. However, Cross (2001) separates the two terms by analysing the definition of "sense of place" in five disciplines. For example, in an environmental psychology work, "sense of place" is "the particular experience of a person in a particular setting" while "spirit of the place" is "the combination of characteristics that gives some locations a special 'feel' or personality" (Steel, 1981 quoted by Cross, 2001, p. 1). Another author also distinguishes the nuance between the two terms: "sense of place is our experience of the spirit of the place in a particular location" (Relph, 2009 quoted by Kapila, 2015, p. 822). For the present article, the distinction is important.

When it comes to the protection of heritage (tangible and intagible), the spirit of the place gains yet another nuance. Thus, the "Québec Declaration on the Preservation of the Spirit of the Place" (2008) states that the "spirit of place is defined as the tangible (buildings, sites, landscapes, routes, objects) and the intangible elements (memories, narratives, written documents, rituals, festivals, traditional knowledge, values, textures, colors, odors, etc.), that is to say the physical and the spiritual elements that give meaning, value, emotion and mystery to place" (Québec Declaration, 2008, Preamble). This vision relativises the concept which gains a "dynamic character, capable of possessing multiple meanings and singularities, of changing through time, and of belonging to different groups" (Québec Declaration, 2008, Preamble). Also, the emphasis is placed on the social aspects as "spirit of the place is transmitted essentially by people" (Québec Declaration, 2008, Transmitting the Spirit of the place, article 8).

The opposition in stance to Norberg-Schulz is evident, as he considers that the place is stable through its essence. The definitory aspect - the essence (genius loci) - can be reinterpreted over time, hence the role of the social component which attributes meaning depending on the context/ epoque. However, constant referencing to the essence ensures, simultaneously, evolution and preservation of the genius loci. This is the process through which, in time, a strong identity of the place (human-built) is consolidated. Implicitly, it means that a place can have "an essential character independent of the human observer" (Hay, 2002, p. 158). The focus is on a quality intrinsec to the place and not on the individual's perception of a place. While refuting the essentialist approach, we must still note the implication stated above similar to that of Massey that places can have a "character of their own" (Massey, 1994).

The loss of meaningful interpretation of the environment, in terms of both space and character is seen as a crisis of place, a condition of modernity associated with lack of urban structure and monotony, with abstract space. However, "all places have character and (...) character is the basic mode in which the world is 'given'" (Norberg-Schulz, 1976, p. 14). 


\section{Summary of the discussion}

We have seen that genius loci is a concept usually associated with strong, positive images, with an experience of "wholeness" and coherence, in a meaningful environment, that allows for identification. The lack of meaning and abstractization leads to a loss of spirit of the place and the feeling of alienation. However, people can still have attachement to a place and a sense of place based on their perception and experiences, but this does not necessarily imply that the place has a strong spirit perceived on a general level.

The theories that define places based on the individual's perception lead to the conclusion that places "have no objective and universally acknowledged meaning" (Hay, 2002, p. 158). In the case of a place seen as a result of collective agreement, it means that the definition of the place is constructed from the inside, by the community, thus the spirit of the place should be explored through local eyes. However, since some places have strong images and characters of their own, one may wonder what is it that gives them enough stability and the posibility to be recognised by local and non-local people? Is it that the built environment can be a physical "summary" of otherwise hidden meanings and can there be a general consensus on its understanding?

\section{SEIZING GENIUS LOCI}

It is clear that, if "genius loci" is to be captured, the approaches are countless, depending on our understanding of the concept. As stated above, an obvious implication is that, if place is perceived as being constructed from the "inside", from community and/or long-term familiarity with a place, local population should be involved in portaying its genius loci. One could either try to understand the local view about the place (example in Kapila's work, 2015) and use it as a point of departure for photographing or use the photo elicitation technique departing from locals'/ residents' photos (Santos' work about the 'experientiation' of a heritage place, 2016). However, since the understanding of place is based on relativity, it would be arguable if, in this case, genius loci is something stable enough to be depicted or if it is only individual experience (sense of place) that can be captured and transmitted (if it can).

Could it be that the genius loci can "show through" in a visual material and be unanimously acknowledged even if it is not necessarily understood or experienced in the same way?

In refering to the understanding of a work of art, Boucher (2008) states: "in order to grasp the work of art in a similar way, they [the observants] must have a common experience and knowledge of the referents. This condition is fufilled in part by a large share of the world's population" (p. 5). In interpreting an artistic depiction of landscape, we bring about our past individual experiences and our cultural background (cultural referents), thus creating a kaleidoscope of singular views of the same place. When talking about the spirit of a place, she makes an interesting point: even if there are multiple interpretations of the same work (in our case a photograph), this does not impeach a general consensus. The spirit of the place is polyvalent based on different levels of reading: "at a first level there is a spirit of the place shared by a large collectivity and further the lecture deepens, there is larger division of readers into sub-groupes (environmentalists, artists, workers, Gâtinais people, Canadians...) until the reading 
becomes an individual affair" (Boucher, 2008, p. 7). It is almost as if the spirit of the place diffuses into individual senses of the place. It might be that this kind of reading is applicable to photographic work also.

\section{Photography and representation}

Given the important place the visual has gained in Western society, it comes about as natural to want to "show" a place and capture its defining traits in a photograph. The proliferation of the visual has often determined an understanding of the world through a particular type of knowledge, up to the point that seeing is easily associated with knowing (Jenks, 1995 quoted in Rose, 2012). This is due to the consideration for a long time that the visual offers a clear, objective, transparent and raw view of the world, it has an implicit "obviousness" (Kearners, 2000), belief which has long been criticised now and which implies that vision precedes knowledge. Foucault rejected this view and contested the equivalence of words and images, the idea that "What is seen and what is described is (...) the same" (Kearnes, 2000, p. 334). He claimed the rupture between image and words and emphasised the importance of understanding how what is being seen is made visible because "The eye (...) is combined or (in the Platonic sense) corrupted with knowledges in making things visible" (Kearnes, 2000, p. 335. Thus, vision does not precede knowledge, but together with it, creates a particular type of visuality, a particular way in which the visible is made vsible. We have come to understand that photography is far from being an objective representation of reality, that it is actually an interpretation of reality and a particular way of understanding the world (Rose, 2012; Scarles, 2004).

This has generated a set of theories and works of the nonrepresentational, which target affect and experience. The interest here is not to understand the meaning of the visual material, but to explore the sensory, the perceptual as it is "no need to interpret, only to unfold, to increase the surface area of experience" (Marks, 2002, quoted by Rose, 2012).

Crang (2010) also advocates for a distancing from the representational, by using visual material as a way to gain "proximal knowledge", that is "context-specific, fragmentary, and often mundane" (Hetherington, 2003 quoted by Crang, 2010, p. 218) rather than "distal knowledge" that targets a global, detached view (p. 218). Through a review of various studies, he shows that visual materials can be used to critique, to refute the presentation of objectifying images, by making appeal to fragmentation and paradoxes of gazes. Visual material can be either used to produce other types of knowledge than the ones that have dominated so far, or to use the method of 'objectivity' as a way to contest that very same objectivity (see his analysis of Ursula Biemann's video essay in Crang, 2010, pp. 216-217).

Oldrup and Carstensen (2012) also propose changing the focus from what meaning the images have to what kind of knowledge they can produce and they explore the understanding of visual methods as social actions. The point is to analyse not the content of the image, but the "practices and processes of taking, choosing, using and interpreting images" by individuals (Oldrup and Carstensen, 2012, p. 229).

We see, therefore, a significant change in the usage of and thinking about photography and visual methodologies in general. This pushes us to critically reflect on the "authentic" feel of a place proclaimed in some photographs (for instance, those of tourist brochures), on what kind of information can be gained or portrayed about the spirit of a place, especially in the context of tangible and intagible aspects, general character and individual sense of place. 


\section{Photo-essay: words - image dichotomy}

As mentioned above, the critical view on the representational function of photography was associated with the discussion about images and words and the acknowledgement that "what we see never resides in what we say. And it is in vain that we attempt to show, by use of images, metaphors or similes, what we are saying" (Foucault, 1970 quoted by Kearnes, 2000). However, the view has sometimes led to claiming the superiority of one method over the other. Oldrup and Carstensen (2012) mention the suggestions that visual methods could provide better knowledge and that this implicitly creates a dichotomy between words and images. It infers the fact that the visual is authentic and not altered, while words are unnatural and strained (Oldrup and Carstensen, 2012, p. 229).

In his exploration of photographic research methods employed in Human Geography, Hall (2009) explains that the contestation of hierarchies of knowledge and authority has led to different approaches in using texts and images, notably in anthropology and sociology. Text has become less of a way to transmit information and more of a way to express experiences (of researchers, of participants in studies or both), and the multiplicity of voices and meanings. There is a constant care not to present images in a way that could constrain to a single meaning. Sometimes this goes as far as to exclude entirely the use of captions with the images (Hall, 2009, p. 459).

As Rose (2012) points out, the relationship between text and photographs in a photo-essay depend on the purpose of the work. Some authors argue this aproach is useful in presenting an argument, while others place more emphasis on the capability it offers to convey subjective experiences (Rose, 2012, p. 319). Most of the times, a photo-essay can serve both purposes, which is why it was chosen as a way of presenting the results obtained on Chefchaouen. Also, Enderson (2005), quoted by Rose (2012), makes reference to sinaesthesic experiences that photographs can trigger, as they "are never merely visual" (p. 320), thus being appropriate to evoke atmospheres, textures and, generally, the 'feel' of a place.

In the current article, text is used as a counterpoint to photographs in order to emphasise the contrast between objective - subjective, general - personal, materiality - intangibility in the perception of genius loci. 


\section{THE SPIRIT OF CHEFCHAOUEN}

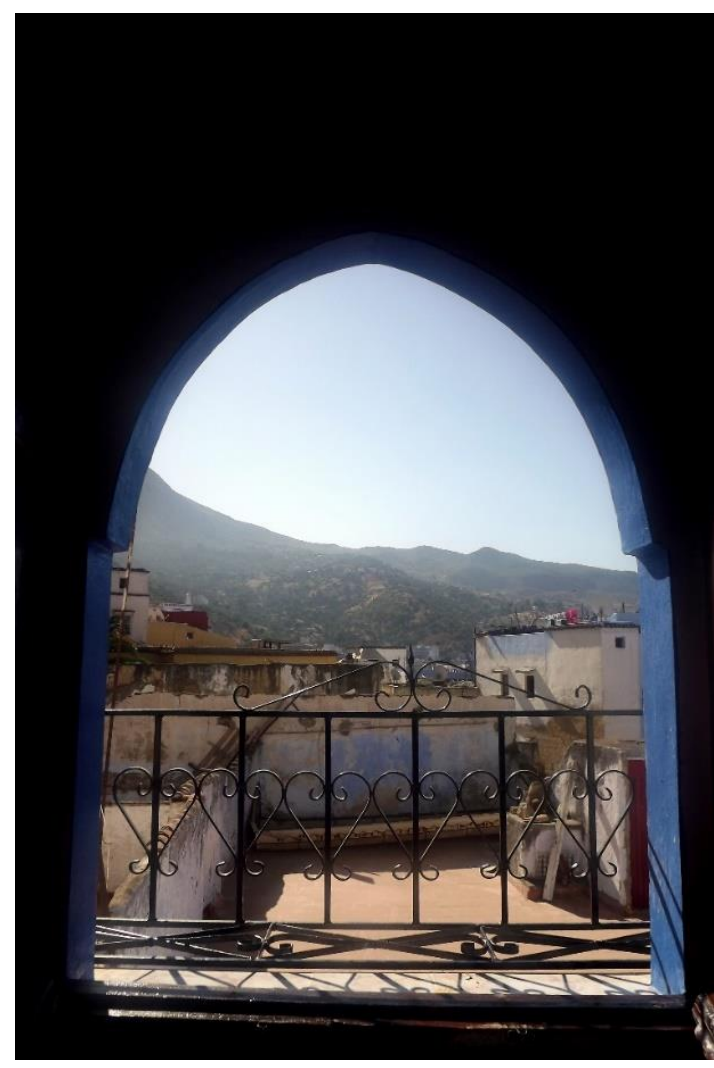

Figure 1: Morning view from the hostel window. The mountains are a constant presence, sentinels watching over the city Source: Iulia Doroftei, September 2015
Chefchaouen, the blue city of Morocco, founded as a small fortress in the $15^{\text {th }}$ century, still wonderfully preserves its core nowadays. It is situated in the Rif region, blossoming from the base of two mountains, where the nucleus is (Figure 2), into the landscape with the newer part of the city. The blue, in its various shades, awaits at the entrance of the old town and slowly embraces everything from walls to doors, windows and even streets and steps. The conglomerate of lowrise buildings, tightly packed next to each other, seems to respond to the sky above through its blending of white and shades of blue (Figure 3). The dense settlement, organically structured, following the level curves, forms a maze-like street network that invites to wandering and step-by step discovery. An intimacy and familiarity with the place installs itself soon enough due to the human scale and density of the settlement. Every street has its own character, though well integrated in the totality: openings to the surrounding landscape or to the sky, narrow labyrinthic paths, vividly multicoloured or soft and pale they all fall under the warm, gentle sun which creates sculptural plays of light and shadow (Figures 4-9). The sea of blue is sometimes animated by playful accents of colour in the form of flower pots or local crafts and works of art displayed at the entrances of boutiques and workshops (Figure 10). Life is slow-paced. General serenity and calm reign over the old city (medina) of Chefchaouen.

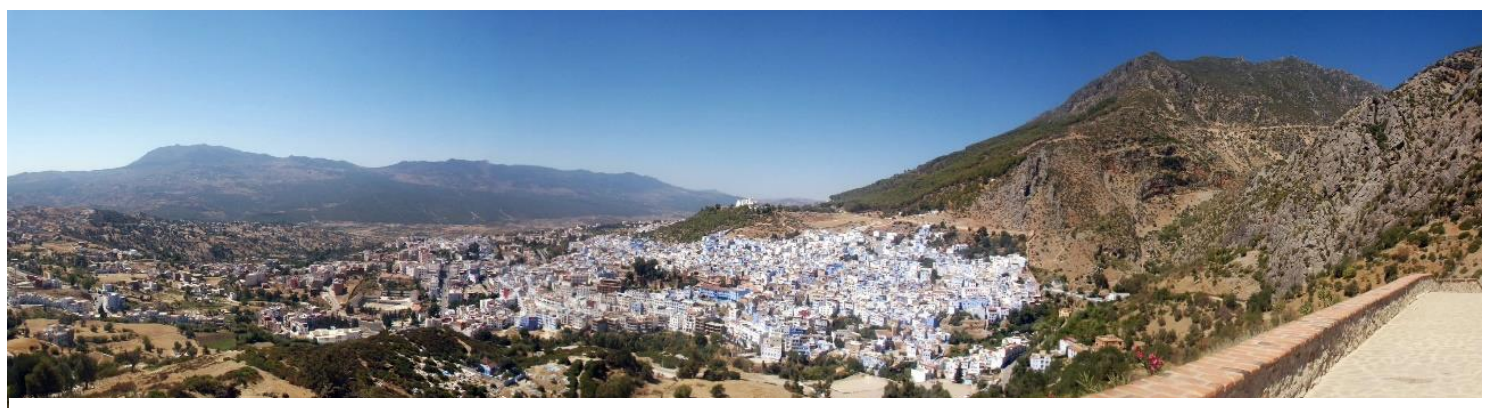

Figure 2: From dense building to extension into the plain field. Chefchaouen seems like a complement of the natural environment, well ingrained into the surrouding landscape 


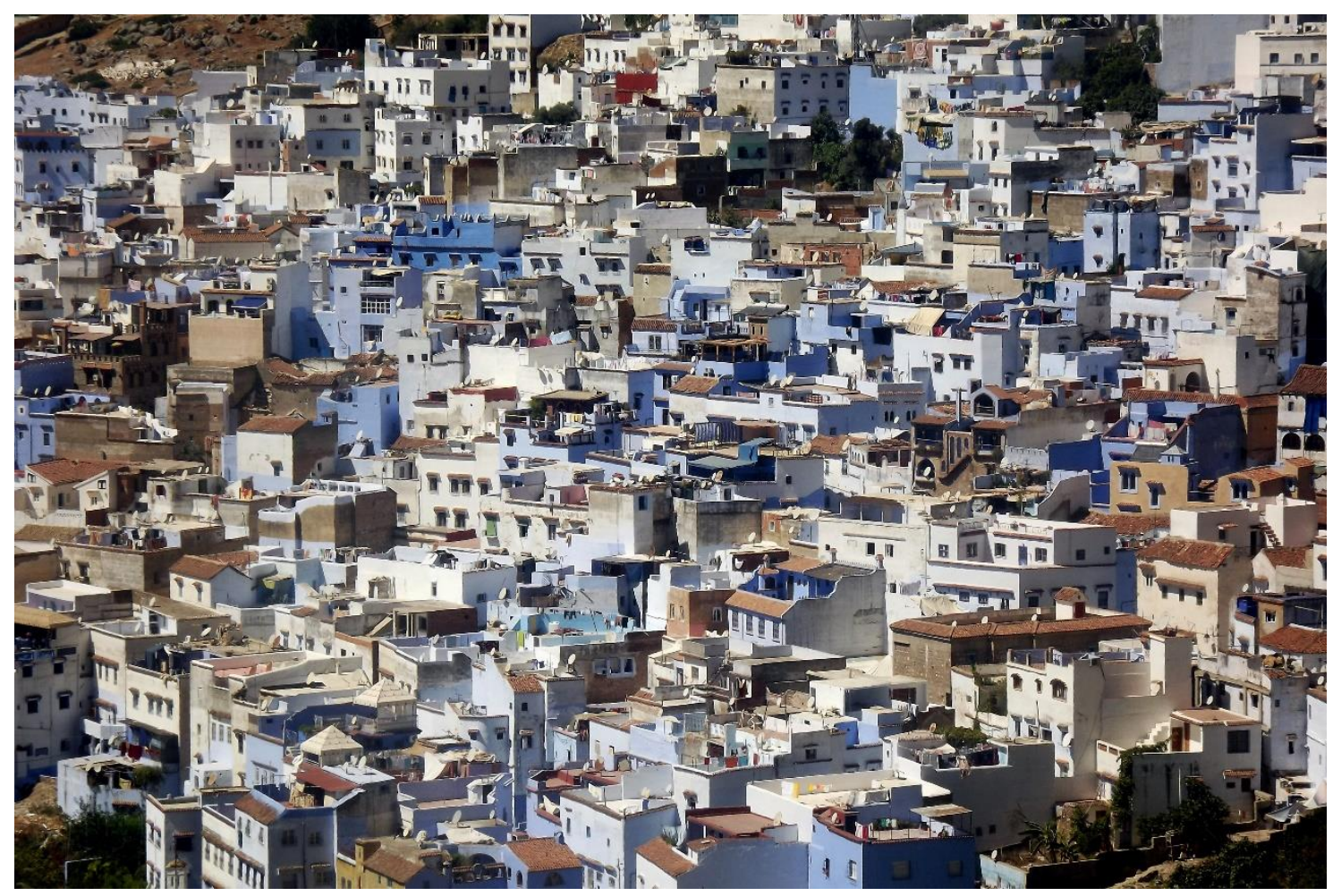

Figure 3: Sky and earth blend through the colour palette of Chefchaouen's buildings. A feel of spontaneity and organicity of the settlement is given off throughout when in place

Source: Iulia Doroftei, September 2015

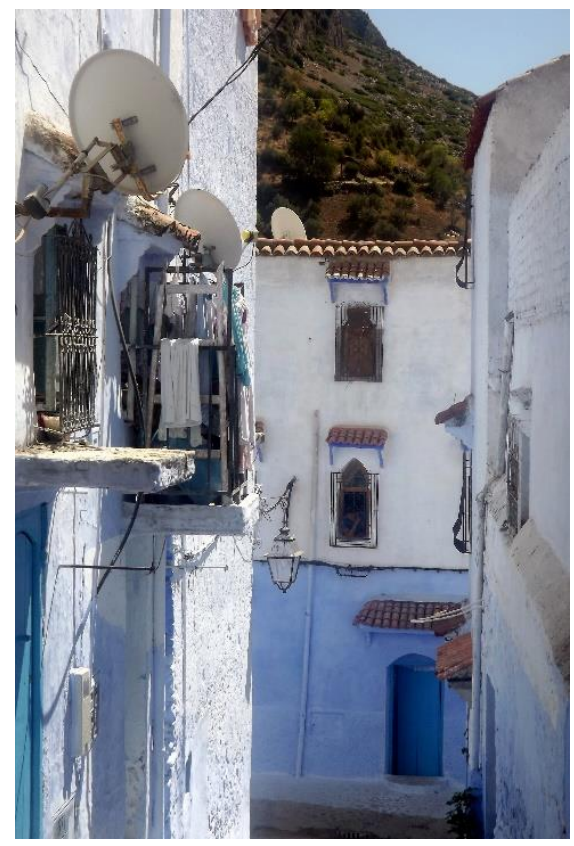

Figure 4: Calm morning with soft tones on a residential street Source: Iulia Doroftei, September 2015

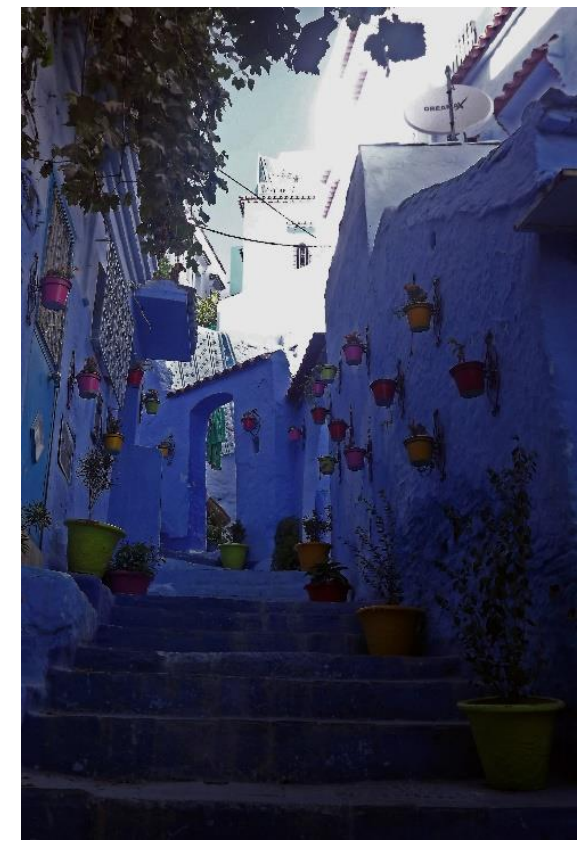

Figure 5: From pale to vivid: the streets are always full of surprising details

Source: Iulia Doroftei, September 2015 


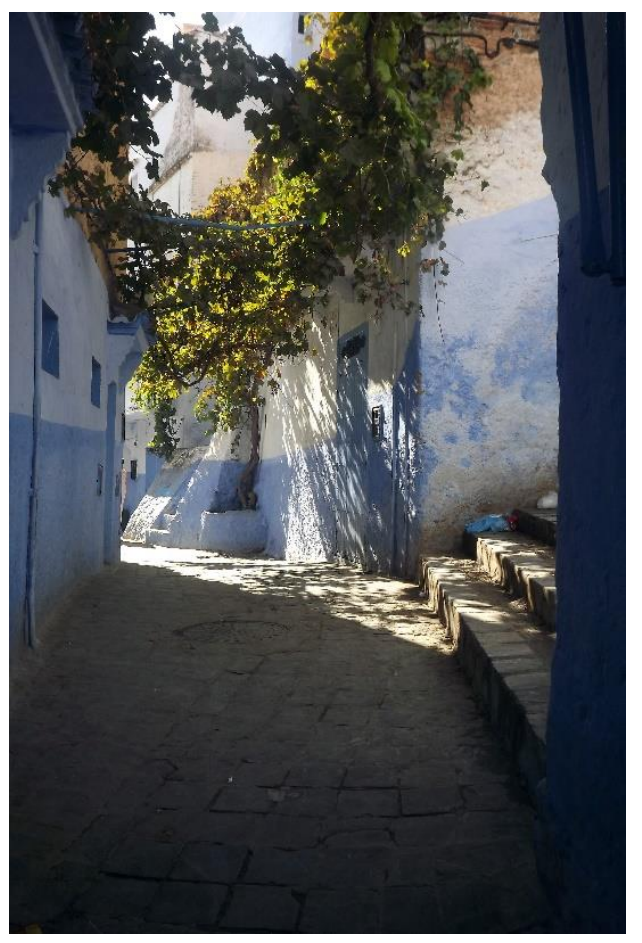

Figure 6: Wandering in the quiet of the afternoon sun

Source: Iulia Doroftei, September 2015

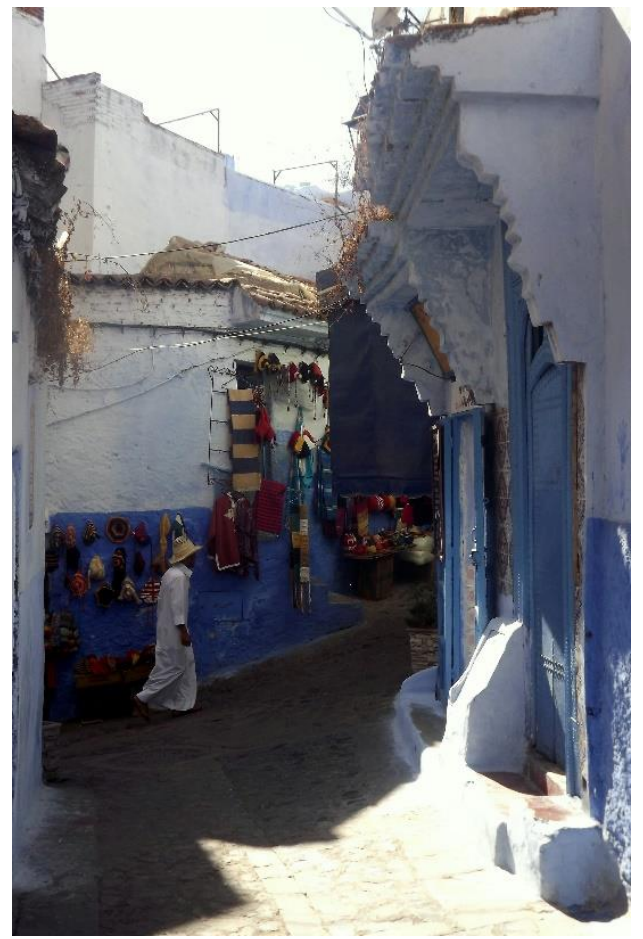

Figure 7: The atmosphere becomes lively through artisanry. The local presence is discrete Source: Iulia Doroftei, September 2015

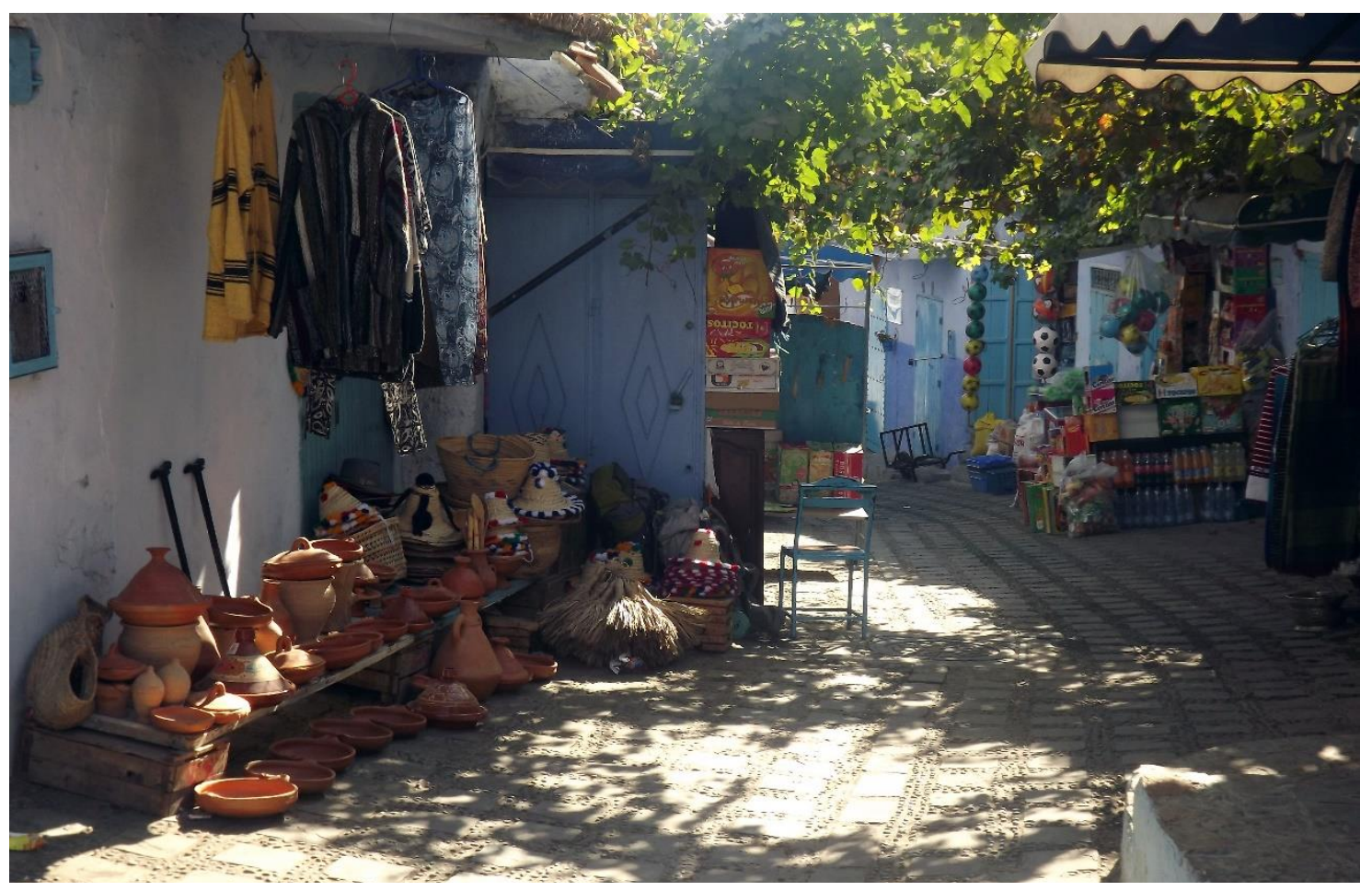

Figure 8: When everything is opened: walking on a street of boutiques

Source: Iulia Doroftei, September 2015 


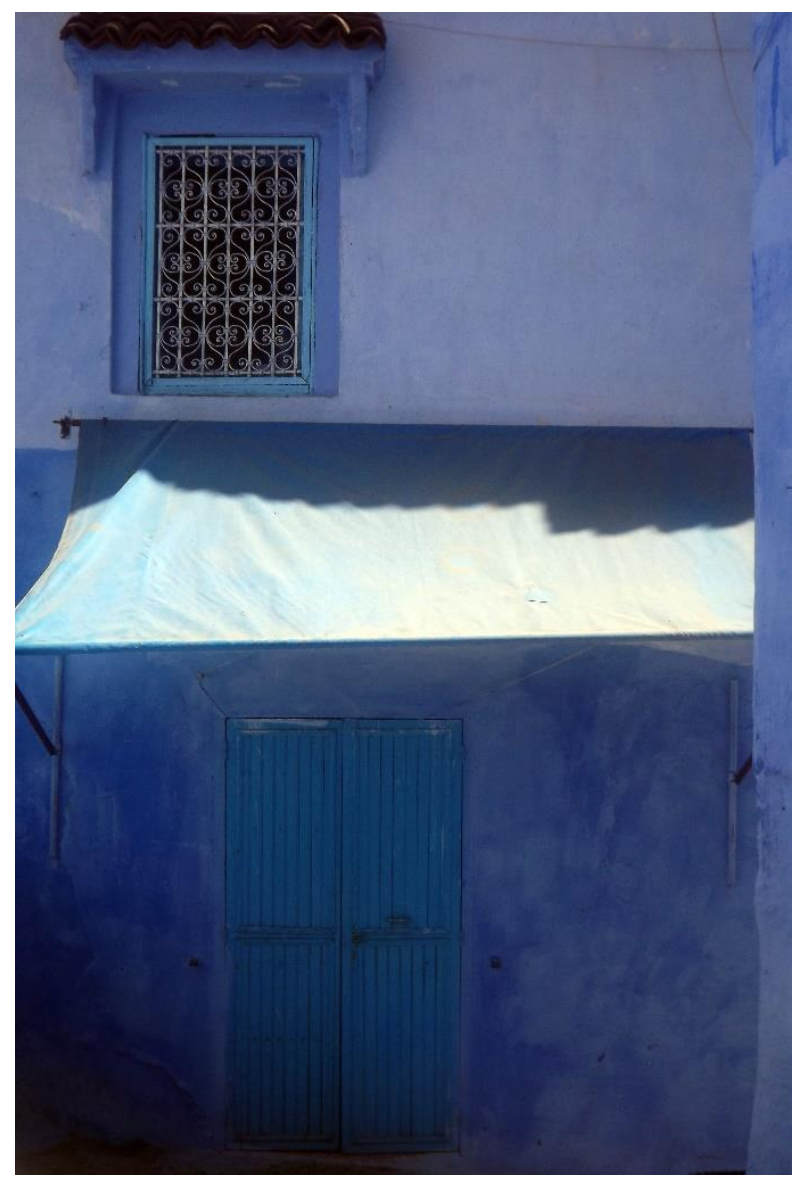

Figure 9: The city's personality seems to me condensed even in small components like doors and windows Source: Iulia Doroftei, September 2015

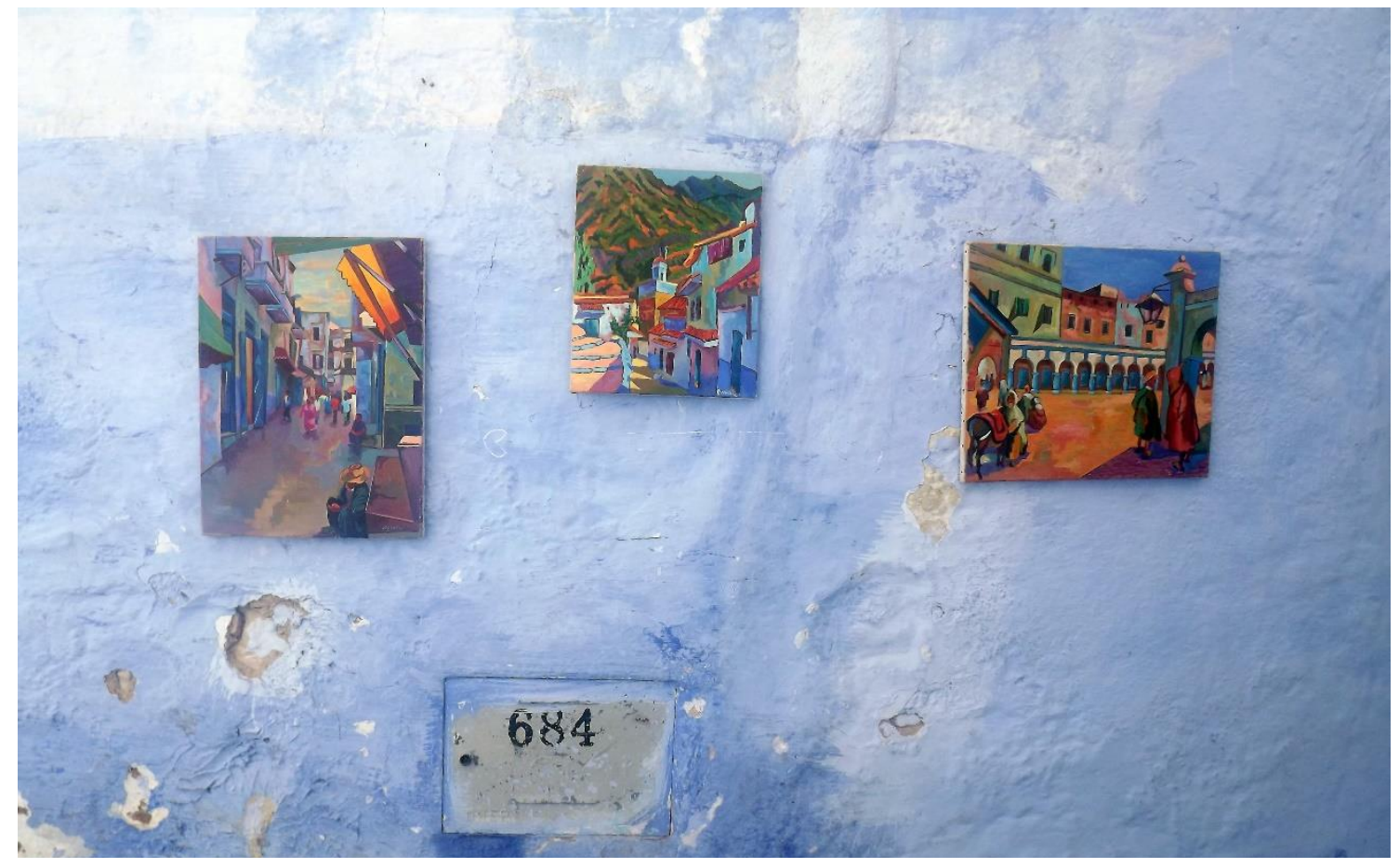

Figure 10: Local art guards the same lively colour palette encountered throughout the city Source: Iulia Doroftei, September 2015 


\section{REFLECTION}

The photo-essay is an attempt to confront the physical manifestation of the character of the place through the built environment, generally recognisable, with the individual interpretation of the place and its personal experiencing. Also, to contest the apparent objective nature of documentary visualities which "have focused on museumified visions of urban space (Crang, 1996) that valorise urban landscapes" (Datta, 2012, p. 1727).

Departing from Norberg-Schulz's idea of "environmental levels" and that a place with a strong spirit, as is the case here, will have it manifest itself on the various levels of the built environment, I have tried to use the photos to create the impression of a documented, objective, gradual analysis of the "imageability" of the settlement. However, the text comes as a counterpoint by bringing into discussion the individual experience, personal sensations, and feelings towards? the place. The captions are not used to constrain to a single interpretation of the image, but to bring into attention that what may seem a disembodied, objective gaze of the place, has personal experiences behind the process of production. The use of verbs such as "seems", "feels" and "walking", "wandering" is supposed to add subjectivity, a 'ghostly' presence to the seeming "facticity" of the photographs inviting the reader to question their true nature. Also the gradual passing from bird-eye view, to the distanced view of streets, to eyelevel walk and details creates the same impression of departing from objectivity to arrive at a purely subjective experience of the place.

The contestation of the apparent raw truth of documentary pictures can lead to a reflection on the plurality of senses of the place based on individual experiences, to the contestation of the essentialist idea of place identity. However, the fact that, as mentioned previously, the photoessay serves both as a means of synaesthesic experiencing and analysis and argumentation, can reveal aspects of the place's "own character", as Massey names it (1994), of its strong personality and its recognisable image on a general level, or, put otherwise, can show components of the genius loci.

It would have been useful to compare different perspectives on the spirit of the place, to use participatory research methods to explore the experiences of local residents and reflect on common and different elements identified by them and the researcher. This was one of the limits of the study as it used previously empiricaly generated materials and there was no possibility of pursuing the investigation afterwards. In this stage, the intention was rather to reflect on and portray the contradictions and oppositions in the concept of spirit of the place and the difficulties in seizing it.

The local presence has not been taken into consideration for several reasons: firstly, no participatory methods could be employed in this stage and the appearance of the objectifying gaze would have been inevitable. Secondly, I wanted to express indeed the discretion of the local presence which is more visibly felt through the plethora of local products displayed, as stated in the essay. Thirdly, the focus of the article was on the materiality of the spirit of the place.

Another interesting direction to pursue would be the investigation of placelessness, of "the loss of place" or of "non-places" (here, understood as in Marc Augé's work, 1995) and to see what types of knowledge can be obtained through visual methods (e.g. about practices in these types of spaces, standardisation, and temporality). For example, Ulrich uses photography to depict consummer culture and, in his series 'Retail', he explores the space of retail shops and the practices that occur in such 'non-places' which "fabricate the 'average man'" (Augé, 1995, p. 100), depersonalised and turned into a simple user. 


\section{CONCLUSION}

Genius loci is a concept whose meaning has varied over time, whose complex nature has made it hard to be defined precisely, particularly as it is dependent on the notion of "place". Despite the amibguity in understanding, there are some features that a large share of the population can recognis, a general agreement can be reached, and in the case of man-made places, the built-environment holds an important role here as a physical concretization of the spirit of a place. The hibrid nature of the concept, its different ways of being perceived and interpreted create tensions between theoretical approaches and materiality, the tangible and the intangible, the general view and the individual sense of place.

Through the use of the photo-essay an attempt has been made to highlight this aspect and to raise awarness about the different levels of "reading" of the genius loci by contraposing objective and subjective information about a place. Also, the work served to challenge the representational function of photography, by implying its underlying subjective motives. However, the photographs, presenting the place at different environmental levels, also allowed for creating a general understanding of the place, thus a partial depiction of its spirit. Therefore, there are multiple types of knowledge gained through this visual method.

A further investigation concerning different perceptions of the spirit of the place could be useful to see, for example, whether, how and where common agreement on the spirit of the place/ sense of the place occurs. Also, a reflection could be made on which visual methods to use in gaining knowledge about contemporary fragmented urban environments, apparently lacking in meaning (spirit).

\section{REFERENCES}

AUGÉ, M. (1995). Non-Places: Introduction to an Anthropology of Supermodernity. Verso Books.

BARON, R.M. (2008). Re-thinking the Spirit of Place (16 ${ }^{\text {th }}$ Assembly of ICOMOS, Québec, Canada), Retrieved 20 July 2016, from http://www.icomos.org/quebec2008/cd/toindex/77_pdf/77-9NSF182.pdf

BOUCHER, L.N. (2008). L'esprit du ieu d'un paysage artialisé (16 ${ }^{\text {th }}$ Assembly of ICOMOS, Québec, Canada), Retrieved 20 July 2016, from http://www.icomos.org/quebec2008/cd/toindex/78_pdf/78-99qB141.pdf

CRANG, M. (2010). Visual Methods and Methodologies. In: DelYSER, D., HERBERT, S., AITKEN, S., CRANG, M., \& McDOWELL, L. (eds.), The SAGE Handbook of Qualitative Geography (pp. 208-225). London: Sage.

DATTA, A. (2012). 'Where is the Global City?' Visual Narratives of London among East European Migrants. Urban Studies, 49(8), 1725-1740.

HADDAD, E. (2010). Christian Norberg-Schulz's Phenomenological Project in Architecture. Architectural Theory Review, 15(1), 88-101.

HALL, T. (2009). The Camera Never Lies? Photographic Research Methods in Human Geography. Journal of Geography in Higher Education, 33(3), 453-462.

HAY, P. (2002). Main Currents in Western Environmental Thoughts. Sydney: University of New South Wales Press Ltd. 
IOAN, A. (2005). Genius Loci. Djinn al locului. Loc (in)toxic(at). Atelier LiterNet. Retrieved 18 August 2016, from http://atelier.liternet.ro/articol/2257/Augustin-Ioan/Genius-Loci-Djinn-al-locului-Locintoxicat.html

JIVÉN, G., \& LARKHAM, P.J. (2003). Sense of Place, Authenticity and Character: A Commentary. Journal of Urban Design, 8(1), 67-81.

KAPILA, D.S. (2015). The Spirit of Place of Bhaktapur, Nepal. International Journal of Heritage Studies, 21(8), 820-841.

KEARNES, M.B. (2000). Seeing is Believing is Knowing: Towards a Critique of Pure Vision. Australian Geographical Studies, 38(3), 332-340.

MASSEY, D. (1994). Space, Place and Gender. Minneapolis: University of Minnesota Press.

MØYSTAD, O. (2012). The Spirit of Place in a Multicultural Society, Retrieved 23 August 2016, from http://www.architecturenorway.no/questions/identity/moystad-on-cns/

NG, V. (2012). A Critical Review on the Problematic Nature of 'Place'. British Journal of Arts and Social Sciences, 5(1), 103-122.

NORBERG-SCHULZ, C. (1976). Genius Loci: Towards a Phenomenology of Architecture. New York: Rizzoli.

OLDRUP, H.H., \& CARSTENSEN, A. (2012). Producing Geographical Knowledge through Visual Methods. Geografiska Annaler: Series B, Human Geography, 94(3), 223-237.

Québec Declaration on the Preservation of the Spirit of the Place, adopted at Québec, Canada, October $4^{\text {th }}$ 2008, Retrieved 11 July 2016, from http://whc.unesco.org/uploads/activities/documents/activity646-2.pdf

ROSE, G. (2012), Visual Methodologies: An Introduction to Researching with Visual Materials. 3rd Edition. London: SAGE.

SANTOS, P.M. (2016). Crossed Gazes over an Old City: Photography and the 'Experientiation' of a Heritage Place. International Journal of Heritage Studies, 22(2), 131-144.

SCARLES, C. (2004). Mediating Landscapes. The Process and Practices of Image Construction in Tourist Brochures of Scotland. Tourist Studies, 4(1), 43-67.

SITTE, C. (1992). Arta construirii orașelor. Urbanismul după principiile sale artistice [The Art of Building Cities. Urbanism according to Its Artistic Principles]. Bucharest: Editura Tehnică.

TURGEON, L. (2008). L'Esprit du lieu : entre le matériel et l'immatériel. Présentation de la thématique du colloque (16 $6^{\text {th }}$ Assembly of ICOMOS, Québec, Canada), Retrieved 20 July 2016, from http://www.icomos.org/quebec2008/cd/toindex/papers_ouverture/inaugural-Turgeon.pdf

WILKEN, R. (2013). The Critical Reception of Christian Norberg-Schulz's Writings on Heidegger and Place. Architectural Theory Review, 18(3), 340-355. 